\title{
Article \\ Study on Gemological Characteristics of Blue Sapphires from Baw-Mar Mine, Mogok, Myanmar
}

\author{
Siming Chen ${ }^{1}$, Honglin Tan ${ }^{1}$, Cun Zhang ${ }^{2}{ }^{(D}$, Yajun Teng ${ }^{3}$ and Endong Zu ${ }^{1, *}$ \\ 1 Faculty of Materials Science and Engineering, Kunming University of Science and Technology, \\ Kunming 650093, China; simu7325@163.com (S.C.); tanhl@kust.edu.cn (H.T.) \\ 2 School of Materials Science and Engineering, Qilu University of Technology (Shandong Academy of Sciences), \\ Jinan 250353, China; geozhangc@163.com \\ 3 Kunming Customs Technology Center, Kunming 650228, China; tengyj44734198@163.com \\ * Correspondence: zend88@163.com
}

Citation: Chen, S.; Tan, H.; Zhang,

C.; Teng, Y.; Zu, E. Study on

Gemological Characteristics of Blue Sapphires from Baw-Mar Mine, Mogok, Myanmar. Crystals 2021, 11, 1275. https://doi.org/10.3390/ cryst11111275

Academic Editors: Taijin Lu, Fei Liu, Tingting Gu and Per-Lennart Larsson

Received: 26 September 2021

Accepted: 14 October 2021

Published: 21 October 2021

Publisher's Note: MDPI stays neutral with regard to jurisdictional claims in published maps and institutional affiliations.

Copyright: () 2021 by the authors. Licensee MDPI, Basel, Switzerland. This article is an open access article distributed under the terms and conditions of the Creative Commons Attribution (CC BY) license (https:// creativecommons.org/licenses/by/ $4.0 /)$.

\begin{abstract}
This paper employs an X-ray powder crystal diffractometer (XRD), an X-ray fluorescence spectrometer (XRF), an ultraviolet-visible-near infrared spectrometer (UV-Vis-NIR), a Fourier infrared spectrometer (FTIR), and a laser Raman spectrometer to systematically investigate the gemological characteristics of blue sapphires from Baw-mar mine, Mogok, Myanmar. The results show that the FTIR spectra and UV-Vis-NIR spectra of the sapphire from this mine are significantly different from those of sapphires from other origins, which can be used to identify sapphires from this mine. The main crystal structure of the mineral sapphire from Baw-mar mine is corundum. The predominant chemical elements are $\mathrm{Al}$ and $\mathrm{O}$, and the color-causing elements are $\mathrm{Fe}, \mathrm{Ti}, \mathrm{V}$, and $\mathrm{Ni}$. The characteristic ultraviolet absorption peak appears at $418 \mathrm{~nm}$, which is mainly caused by the $\mathrm{d}$ - $\mathrm{d}$ transition of $\mathrm{V}^{3+}$ ions. The intensity change of the $946 \mathrm{~nm}$ ultraviolet absorption peak indicates that the presence of $\mathrm{Ni}^{2+}$ ions may aggravate the gray tone of sapphire and reduces its transparency. Compared with sapphires from other origins, sapphires from this mine have three characteristic infrared peaks of kaolinite at 930,1025 , and $1110 \mathrm{~cm}^{-1}$, of which the single peak at $930 \mathrm{~cm}^{-1}$ is attributed to $-\mathrm{OH}$ translation, and the double peaks at 1025 and $1110 \mathrm{~cm}^{-1}$ are attributed to the Si-O stretching vibration. The peaks at $369,410,437,565,633$, and $739 \mathrm{~cm}^{-1}$ in the Raman spectra are attributed to $\left[\mathrm{AlO}_{6}\right]$ octahedron vibration. Our work provides insight into detailed spectroscopy data of blue sapphires from this mine and the identification of sapphires from different origins through spectroscopic characteristics.
\end{abstract}

Keywords: sapphire; gemological characteristics; spectroscopy; Baw-mar mine; Myanmar

\section{Introduction}

Sapphire is one of the top five most precious gemstones in the world. In recent years, with the rapid development of the domestic colored gemstone market, sapphires from different origins and mines have emerged continuously, and prices vary greatly. Therefore, it is very important to conduct identification studies on sapphires from specific origins and mines.

X-ray diffraction acts as a powerful tool to analyze the crystallinity, crystal structure, and mineral phase of gemstones, as well as to calculate gem cell parameters. X-ray fluorescence spectroscopy is a powerful method to detect the types and contents of gem elements, and the analysis scope covers major elements and trace elements. Ultravioletvisible absorption spectroscopy is mainly used to study the color-causing mechanism of gems, and to determine the types of color-causing ions in gems by absorption peak positions. Infrared spectroscopy can accurately reflect the molecular structure of gems and serve as an important tool for identifying hydroxyl, water and various functional groups in gems. Laser Raman spectroscopy is an effective method to investigate the molecular composition, molecular vibration frequency, and inclusion composition of gems, and it 
is a complementary technique to infrared spectroscopy [1]. These analytical methods are widely used in the identification and study of gemstones.

Sapphire is a mineral of the corundum group, which is mainly generated in igneous rocks, metamorphic rocks, and alluvial deposits. Different origins and mines will affect the various properties of gemstones, such as color, chemical composition, spectral characteristics and inclusions [2]. The alkaline basalt-type sapphires from Australia and China are predominately produced under reducing conditions, and all have an infrared absorption peak of $3310 \mathrm{~cm}^{-1}$ [3], which disappears when they undergo oxidative heating during transportation. Harlow and Bender [4] suggested that the abnormally enriched Si-Ca sapphire from Mogok mine usually has white mineral inclusions, and the contents of $\mathrm{Ga}, \mathrm{B}, \mathrm{Sn}$, and Ni are also increased significantly based on an electron probe and a laser ablation-inductively coupled plasma mass spectrometer. Palanza et al. [5] applied Raman microscopy to study the inclusion and geographic origin of sapphires from Australia, Madagascar, Sri Lanka, Thailand, Tanzania, and Vietnam, and found that zircon can act as a clue to indicate the genesis of alkaline basalt, whereas diaspore, calcite, carbon dioxide, and sulfur are typical genetic inclusions in metamorphic deposits. Peucat et al. [6] proposed that the combined use of the $\mathrm{Ga} / \mathrm{Mg}$ ratio and Fe concentration are effective tools for distinguishing metamorphic sapphire from magmatic blue sapphire. Sapphires with alkaline basalt origin in Southeast Asia, China, and Africa usually have a higher Fe content and $\mathrm{a} \mathrm{Ga} / \mathrm{Mg}$ ratio $>10$, while the metamorphic sapphires from Mogok and Sri Lanka have a lower Fe content and a $\mathrm{Ga} / \mathrm{Mg}$ ratio $<10$.

This paper gives a brief overview of the geological information of the Baw-mar mine, and systematically studies the crystal structure, chemical compositions, and spectroscopic characteristics of the blue sapphire from this mine. The attributes of its spectral peaks were analyzed in detail, and the peak positions of sapphires from other famous origins were compared and distinguished to identify sapphires from this mine. Moreover, our study aims to present detailed identification data of blue sapphire from Baw-mar mine, which provides a scientific basis for the study of its mineralization environment and post-optimization processing.

\section{Materials and Methods}

\subsection{Geological Background of the Baw-Mar Mine}

The Baw-mar mine site is located in the northwest of Kyat Pyin west of Mogok, 12 miles away from Mogok ( $\left.22^{\circ} 55^{\prime} 39.9^{\prime \prime} \mathrm{N}, 96^{\circ} 24^{\prime} 43^{\prime \prime} \mathrm{E}\right)$. The geology of the mine is complex, mainly composed of a series of high-grade regionally metamorphosed rocks, including granite, garnet-biotite gneiss, calcsilicate rocks, and graphite marble (Figure 1) [7, 8]. Blue sapphires are formed in intrusive dykes, which are mainly composed of syenite. The main mineral of syenite is feldspar, which is an intrusive rock lacking quartz and has a high aluminum-silicon ratio. These syenites are formed in the exposed granite pockets and intrude into the weathered gneiss. After highly weathered and brecciated, the feldspar becomes kaolinite, and finally the sapphires are embedded in the clay pockets [9].

\subsection{Materials}

The experimental samples are 16 rough sapphire stones (samples labelled as M1 to M16) from the Baw-mar mine in Mogok, Myanmar. They are mainly massive and thick, with brownish yellow erosions and off-white materials on the surface. The colors are mostly light blue and gray blue with an uneven distribution. It can be observed that there are double crystals and hexagonal ribbons with developed cracks, and dark-colored impurities can also be observed in the cracks (Figure 2). In order to ensure the accuracy of the experimental results and exclude the influence of rough surface unevenness and altered minerals on the test results, another 9 rough stones were randomly selected and cut along the vertical c-axis into 9 curved samples (samples labelled as MD1 to MD9) with a size of approximately $9 \mathrm{~mm} \times 7 \mathrm{~mm} \times 4 \mathrm{~mm}$ (Figure 3). The samples were subjected to gemological and spectroscopical analysis. 


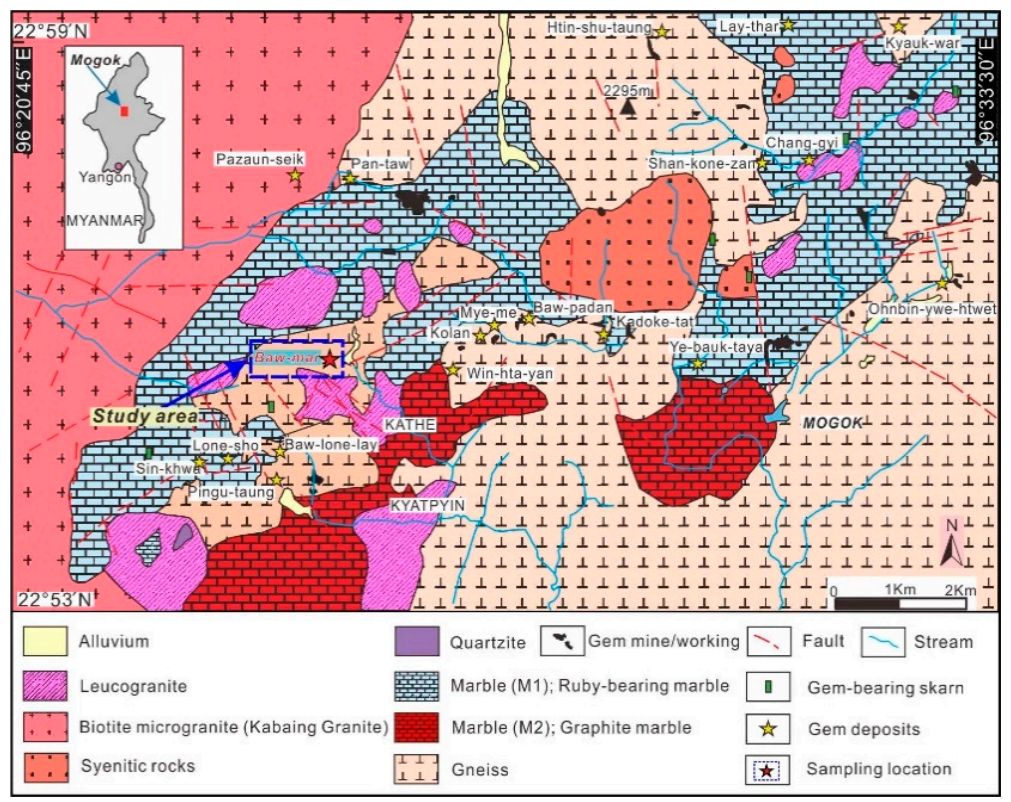

Figure 1. Regional geological map showing general distribution of the ruby/sapphire mine/workings and geological settings of the Mogok gemfield, Myanmar. The sampling location is shown by blue box (modified after [8]).

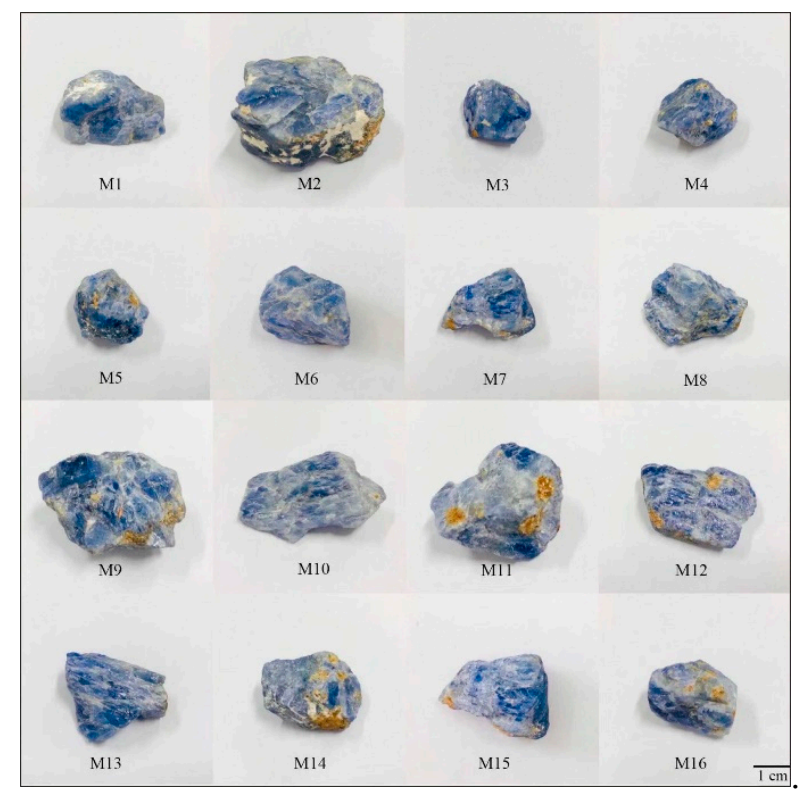

Figure 2. Rough sapphires from Baw-mar Mine.

\subsection{Methods}

The X-ray diffraction analysis was performed on the Rigaku Ultima IV series X-ray powder crystal diffractometer (Akishima-shi, Tokyo). We adopted $\mathrm{Cu} \mathrm{K} \alpha$ rays, a Ni filter, a voltage of $200 \mathrm{~V}$, a current of $20 \mathrm{~A}$, continuous scanning, a scanning speed of $5^{\circ} / \mathrm{min}$, a scanning range of $10^{\circ}-90^{\circ}$, and angle measurement accuracy of $0.02^{\circ}$. The sample was ground into a powder of about 200 mesh with a corundum mortar. The X-ray fluorescence spectroscopy test was completed on the Axios (PW4400/40) instrument of PANalytical (Almelo, The Netherlands), using a Rh target X-ray tube, power $4 \mathrm{~kW}$, with test element range $\mathrm{Be}^{4}-\mathrm{U}^{92}$. A powder sample of 200 mesh was also used. UV-Vis-NIR spectroscopy analysis was completed on the FUV-007 ultraviolet-visible-near infrared spectrometer in 
Shenzhen City, China. The test condition uses reflection, at a resolution of $1.5 \mathrm{~nm}$, a signalto-noise ratio $>1000: 1$, and a test range of 220-1000 nm. The infrared spectroscopy test was performed on the Germany Bruker TENSOR27 Fourier infrared spectrometer. Test conditions: test range $400 \sim 4000 \mathrm{~cm}^{-1}$, resolution $4 \mathrm{~cm}^{-1}$, scanning frequency $10 \mathrm{kHz}$, sample scanning time is $16 \mathrm{~s}$. Collect multiple scans to improve accuracy. The laser Raman spectroscopy test was conducted on the American Thermo Fisher Scientific DXR Raman Microscope Raman spectrometer. The wavelength used was $785 \mathrm{~nm}$, our instrument set allowed a spectral resolution of $4-8 \mathrm{~cm}^{-1}$. We used a scanning time of $20 \mathrm{~s}$ with a spectrum in an extending mode spanning $100-2000 \mathrm{~cm}^{-1}$. The spot size was $1.6 \mu \mathrm{m}$. Filters allowed us to set the laser power on the sample at around $20 \mathrm{~mW}$. Before each session, the spectrometer was calibrated at $520 \mathrm{~cm}^{-1}$ with a silicon standard.

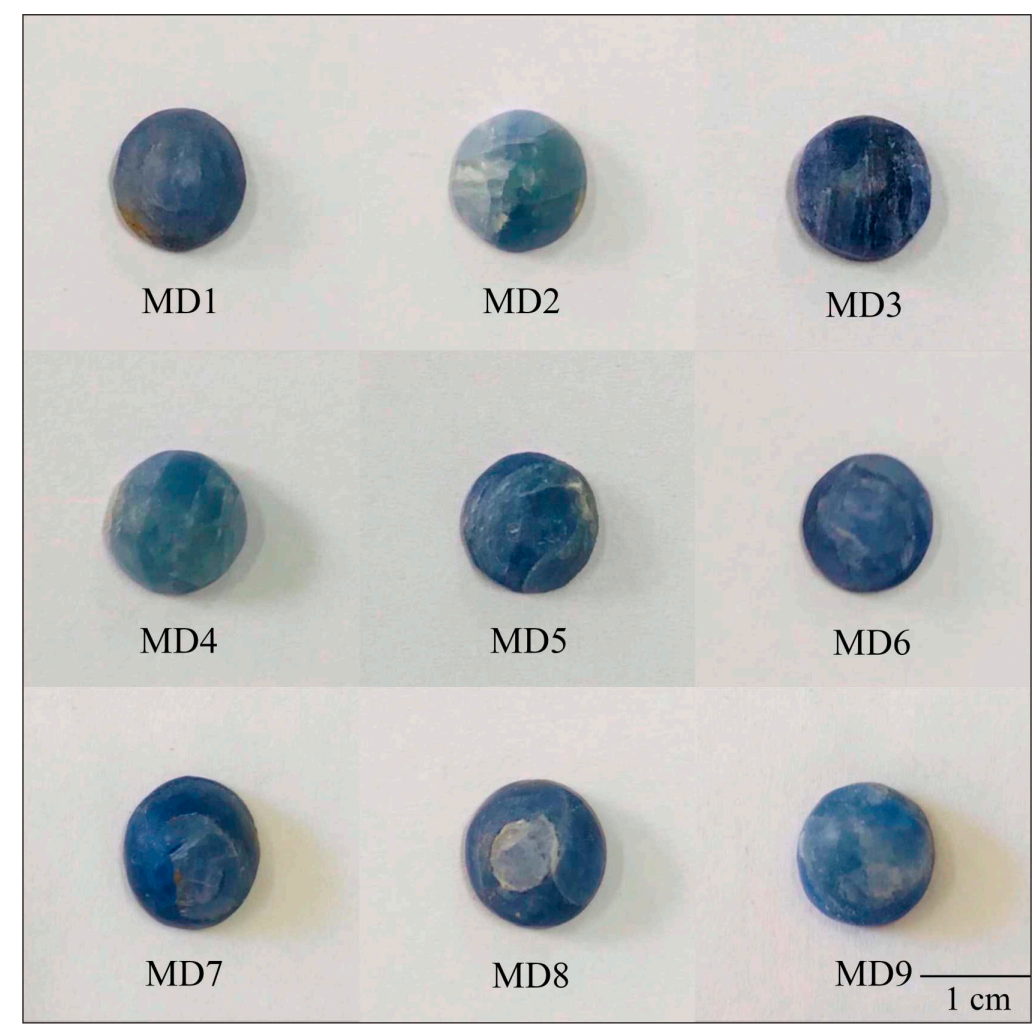

Figure 3. Cutting samples of sapphires from the Baw-mar mine.

\section{Results and Discussion}

\subsection{Gemological Characteristics}

Nine specimens (MD1 to MD9) of curved surfaces that were cut and ground without being polished were selected for conventional gemological feature testing. The sample is different shades of blue with the uneven color distribution. The refractive index is 1.76 , and the density is $3.97-4.03 \mathrm{~g} / \mathrm{cm}^{3}$. The samples are translucent-slightly transparent with developed fissures and have a light blue-light yellow or light blue-dark blue weak dichroism. The fluorescence is inert under long- and short-wave ultraviolet lamps. No solid inclusions were found under the gem microscope, but flat color bands and broken structures at the edges of cracks were occasionally observed.

\subsection{X-ray Diffraction Analysis}

Six curved samples corresponding to the remaining rough stones after cutting were randomly selected, and their edges were cut into small pieces and ground into 200-mesh powder with corundum mortar for XRD testing. The X-ray diffraction analysis results show that the sapphires from Mogok Baw-mar mine in Myanmar have strong diffraction peaks at $3.47,2.55,2.37,2.08,1.73,1.60,1.54,1.51,1.40,1.37$, and $1.23 \AA$, which are similar to the 
standard corundum diffraction peak position (PDF-2004 99-0036) (Figure 4a). Moreover, a characteristic peak at $6.10 \AA$ appears in the diffraction pattern. Combining the FTIR spectra and comparing the diffraction peak position of standard diaspore, it is inferred that it represents diaspore. The off-white material on the surface of the rough samples mainly exhibits strong diffraction peaks at 7.12, 4.97, 4.46, 3.56, 3.47, 3.35, 2.56, 2.34, 2.08, $1.99,1.66,1.60,1.48,1.40$, and $1.37 \AA$, which are similar to the standard kaolinite diffraction peak position (PDF-2004 78-2110) (Figure 4b), indicating that it is kaolinite.

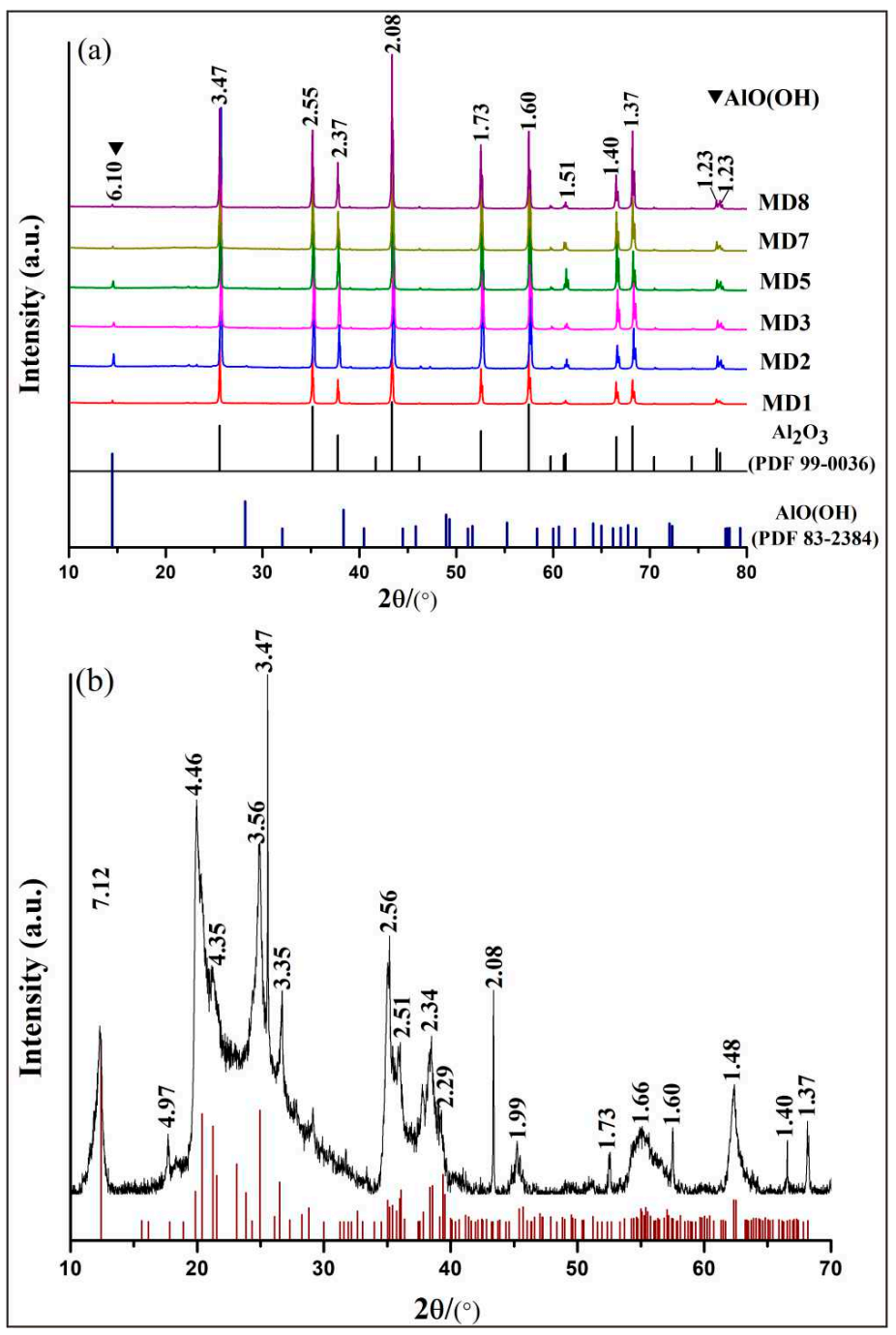

Figure 4. (a) Representative XRD diffraction pattern of white powder on sapphire and rough surface. (b) Off-white material on the surface of the rough sample.

\subsection{X-ray Fluorescence Spectroscopy}

The chemical composition results show (Table 1) that the predominant constituent elements of sapphires in the Baw-mar mine are $\mathrm{Al}$ and $\mathrm{O}$, containing a small amount of $\mathrm{Si}, \mathrm{Fe}$, and $\mathrm{Ti}$. The average content of Fe element is $0.266 \mathrm{Wt} . \%$, and the average content of Ti element is $0.019 \mathrm{Wt} . \%$, both of which are significantly higher than the content of $\mathrm{Fe}$ $(0.014 \mathrm{Wt} . \%-0.082 \mathrm{Wt} . \%)$ and $\mathrm{Ti}(0.003 \mathrm{Wt} . \%-0.012 \mathrm{Wt} . \%)$ compared with other high-quality sapphires [8]. These sapphires also contain trace elements of $\mathrm{V}, \mathrm{Ga}, \mathrm{Ni}$, and $\mathrm{Cr}$. The samples MD1, MD2, MD4, and MD8 have high contents of impurities such as Ni and Cr elements, so the gray tone is obvious, with relatively poor transparency. The sapphires contain both Fe and Ti elements, leading to their blue color. A small amount of $V$ has a certain effect on the color of sapphires, which is verified in the UV-Vis-NIR spectra. 
Table 1. Chemical composition of sapphires from Baw-mar mine (Wt.\%).

\begin{tabular}{ccccccccccc}
\hline Sample & Al & $\mathbf{O}$ & $\mathbf{S i}$ & $\mathbf{F e}$ & $\mathbf{T i}$ & $\mathbf{V}$ & $\mathbf{N i}$ & $\mathbf{C r}$ & $\mathbf{G a}$ & $\mathbf{M g}$ \\
\hline MD1 & 50.770 & 46.864 & 0.159 & 0.313 & 0.015 & 0.003 & 0.024 & - & 0.005 & 0.030 \\
MD2 & 51.044 & 47.117 & 0.182 & 0.275 & 0.013 & 0.004 & 0.012 & 0.008 & 0.006 & - \\
MD3 & 50.741 & 46.838 & 0.128 & 0.403 & 0.025 & 0.002 & - & - & 0.004 & 0.010 \\
MD4 & 51.149 & 47.215 & 0.135 & 0.248 & 0.017 & 0.005 & 0.016 & 0.009 & 0.006 & - \\
MD5 & 51.003 & 47.079 & 0.158 & 0.215 & 0.016 & 0.003 & - & 0.006 & 0.004 & - \\
MD6 & 51.039 & 47.112 & 0.135 & 0.221 & 0.017 & 0.003 & 0.009 & - & 0.005 & 0.020 \\
MD7 & 50.723 & 46.821 & 0.140 & 0.266 & 0.031 & 0.003 & - & - & 0.004 & 0.020 \\
MD8 & 51.485 & 47.525 & 0.143 & 0.257 & 0.020 & 0.004 & 0.011 & 0.014 & 0.006 & - \\
MD9 & 51.156 & 47.221 & 0.175 & 0.200 & 0.016 & 0.004 & - & 0.007 & 0.005 & - \\
Average & - & - & - & 0.266 & 0.019 & 0.003 & - & - & - & - \\
\hline
\end{tabular}

\subsection{UV-Vis-NIR Spectroscopy Analysis}

UV-Vis-NIR spectra shows (Figure 5) that the narrow absorption band of the sample at $321 \mathrm{~nm}$ is caused by $\mathrm{O}^{2-}-\mathrm{Fe}^{3+}$ charge transfer [10]. The absorption peak at $382 \mathrm{~nm}$ is attributed to the d-d transition of $\mathrm{Fe}^{3+}$ in the crystal field: ${ }^{6} \mathrm{~A}_{1} \rightarrow{ }^{4} \mathrm{~T}_{2}\left({ }^{4} \mathrm{D}\right)$. As the valence electrons of $\mathrm{Fe}^{3+}$ transition from the ground state to the excited state in the crystal field are spin forbidden, the absorption at $382 \mathrm{~nm}$ is weak [10]. The absorption peaks at 370 and $454 \mathrm{~nm}$ are caused by the $\mathrm{Fe}^{3+}-\mathrm{Fe}^{3+}$ ion pair. The pairing of $\mathrm{Fe}^{3+}$ will increase the absorption [11]. The narrow absorption band centered at $418 \mathrm{~nm}$ is attributed to the d-d transition of $\mathrm{V}^{3+}$ [12], resulting in a broad absorption near the purple region. The $500-600 \mathrm{~nm} \mathrm{ab-}$ sorption band centered at $585 \mathrm{~nm}$ is caused by $\mathrm{Fe}^{2+}-\mathrm{Ti}^{4+}$ ion pair charge transfer, which absorbs $2.11 \mathrm{eV}$ energy and makes the sapphire blue [12]. As the sample's blue tone increases, $585 \mathrm{~nm}$ absorption evidently increases. The $700-800 \mathrm{~nm}$ broad absorption band is attributed to the charge transfer of $\mathrm{Fe}^{2+}-\mathrm{Ti}^{4+}$ and $\mathrm{Fe}^{2+}-\mathrm{Fe}^{3+}$ ions, which causes the gray-blue hue of sapphire [13]. The gray-blue hue is more pronounced, and the absorption peaks at $746 \mathrm{~nm}$ and $764 \mathrm{~nm}$ are more obvious. The $946 \mathrm{~nm}$ absorption peak is related to the charge transfer of $\mathrm{Fe}^{2+}-\mathrm{Fe}^{3+}$ and $\mathrm{Fe}^{3+}-\mathrm{Ni}^{2+}$ ion pairs [14]. The peak intensity of samples MD1, MD2, and MD4 increases due to the relatively high Ni content.

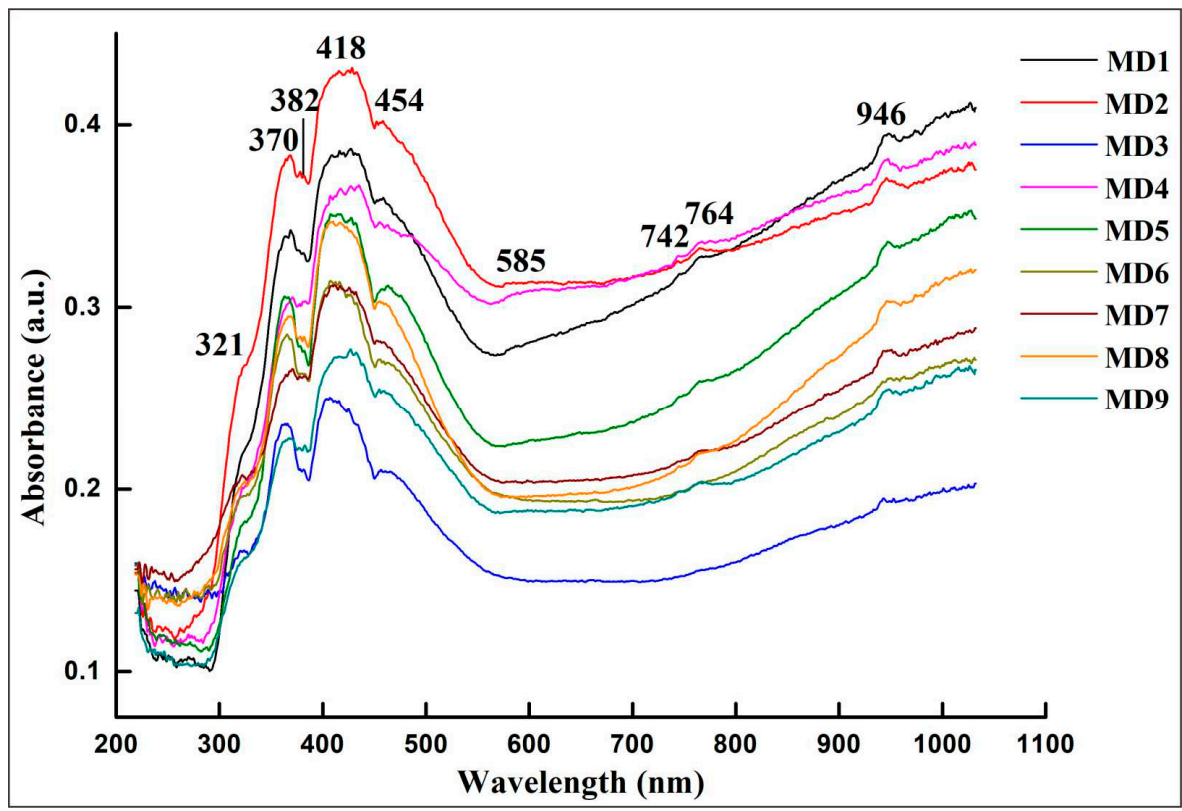

Figure 5. Representative UV-Vis-NIR spectra of sapphires.

Blue sapphires from other locations, such as Madagascar, Sri Lanka, Shandong, Thailand, and other origins, did not show the $418 \mathrm{~nm} \mathrm{~V}^{3+} \mathrm{d}-\mathrm{d}$ transition absorption peak (Table 2). The absorption peak caused by $\mathrm{Fe}^{2+}-\mathrm{Fe}^{3+}$ charge transfer in the near-infrared 
region is mainly located near $860 \mathrm{~nm}$, while the peak position of sapphires from Baw-mar mine usually appears at $946 \mathrm{~nm}$. Therefore, it is inferred that the $418 \mathrm{~nm}$ absorption peak is the characteristic ultraviolet absorption peak of sapphires from Baw-mar mine. The nearinfrared region shifts to the long-wave direction due to $\mathrm{Ni}$ participating in the color of $\mathrm{Fe}^{3+}-\mathrm{Ni}^{2+}$ charge transfer.

Table 2. UV-Vis absorption peak frequency and attributes of sapphires in this study and other locations (nm).

\begin{tabular}{|c|c|c|c|c|c|}
\hline Sapphire Varieties & $\begin{array}{l}\text { Sapphire Curved Sample } \\
\text { from Baw-Mar Mine }\end{array}$ & $\begin{array}{c}\text { Madagascar } \\
{[8]}\end{array}$ & $\begin{array}{c}\text { Sri Lanka } \\
{[10]}\end{array}$ & $\begin{array}{c}\text { Shandong, China } \\
\text { [11] }\end{array}$ & $\begin{array}{c}\text { Thailand } \\
\text { [12] }\end{array}$ \\
\hline $\mathrm{Fe}^{3+} \mathrm{d}-\mathrm{d}$ transition & 382 & 388 & 388 & 387 & 388 \\
\hline $\mathrm{V}^{3+} \mathrm{d}-\mathrm{d}$ transition & 418 & - & - & - & - \\
\hline $\mathrm{O}^{2-}-\mathrm{Fe}^{3+}$ charge transfer & 321 & - & - & - & - \\
\hline $\mathrm{Fe}^{3+}-\mathrm{Fe}^{3+}$ charge transfer & 369,454 & 377,451 & 388,451 & 377,451 & 377,450 \\
\hline $\mathrm{Fe}^{2+}-\mathrm{Ti}^{4+}$ charge transfer & 585 & 579 & 565 & 589 & 575 \\
\hline $\mathrm{Fe}^{2+}-\mathrm{Ti}^{4+}$ and $\mathrm{Fe}^{2+}-\mathrm{Fe}^{3+}$ charge transfer & 742,765 & - & - & - & 710 \\
\hline $\mathrm{Fe}^{2+}-\mathrm{Fe}^{3+}$ and $\mathrm{Fe}^{3+} \mathrm{Ni}^{2+}$ charget ransfer & 946 & - & - & 863 & 860 \\
\hline
\end{tabular}

\subsection{FTIR Spectroscopy Analysis}

Eight samples of rough and curved samples were randomly selected for FTIR spectroscopy testing. The FTIR spectra results show (Figure 6) that the absorption peaks at 485,519 , and $633 \mathrm{~cm}^{-1}$ are attributed to the Al-O structural vibration and are characteristic peaks of $\mathrm{Al}_{2} \mathrm{O}_{3}$, consistent with the standard infrared peaks of corundum [15]. The $650-850 \mathrm{~cm}^{-1}$ absorption band splits into two weak absorption peaks of 729 and $803 \mathrm{~cm}^{-1}$, indicating that the corundum crystal structure is distorted when the impurity ion isomorphism replaces $\mathrm{Al}^{3+}$, leading to a decrease in symmetry and a splitting of the absorption band [15]. There are five weak peaks at 930, 1025, 1110, 3619, and $3696 \mathrm{~cm}^{-1}$ of the rough stone, and they are attributed to kaolinite, of which $930 \mathrm{~cm}^{-1}$ is attributed to kaolinite -OH translation, caused by internal hydroxyl groups. The peaks at 1025 and $1110 \mathrm{~cm}^{-1}$ are attributed to Si-O stretching vibration. The peaks at 3619 and $3696 \mathrm{~cm}^{-1}$ are attributed to -OH vibration, which belong to the absorption of outer and inner hydroxyl groups, respectively [16]. There are only two absorption peaks at 3619 and $3696 \mathrm{~cm}^{-1}$ in the curved sample, and the peak attribution is shown in Table 3. In the spectra of rough and curved samples, there are peaks at 1988 and $2123 \mathrm{~cm}^{-1}$, both attributed to diaspore hydroxyl frequency-doubled vibrations [16], indicating that these Myanmar Mogok sapphires originated in metamorphic or intrusive rocks. The crystallized sapphires experienced crustal movement or magma infusion, and reacted with water-rich hydrothermal fluid to eventually form diaspore [17].

The sapphires from Thailand, China, and Australia produced from alkaline basalt deposits have strong reducibility in their crystal growth environment, and - $\mathrm{OH}$ absorption peaks appear in the $3000-3500 \mathrm{~cm}^{-1}$ band of their FTIR spectra, with $3310 \mathrm{~cm}^{-1}$ being the strongest spectral feature [18]. Meanwhile, the sapphire from Baw-mar mine does not show this peak, which is speculated to be related to the genesis of the deposit. In addition, the characteristic absorption peaks of 930,1025 , and $1110 \mathrm{~cm}^{-1}$ kaolinite did not appear in sapphires from other famous origins.

\subsection{Raman Spectroscopy}

In the corundum crystal structure, $\mathrm{O}^{2-}$ is the most densely packed hexagonal along the vertical cubic axis, $\mathrm{Al}^{3+}$ is filled in the voids formed by $\mathrm{O}^{2-}$, filling two-thirds of the octahedral voids, and $\left[\mathrm{AlO}_{6}\right]$ octahedrons are connected in a coplanar direction along the optical axis, and connected in a coplanar direction perpendicular to the optical axis. According to group theory analysis, the normal vibration mode of corundum is: $\mathrm{T}_{\mathrm{g}}=2 \mathrm{~A}_{1 \mathrm{~g}}+$ $3 \mathrm{~A}_{2 \mathrm{~g}}+5 \mathrm{E}_{\mathrm{g}}+2 \mathrm{~A}_{1 \mathrm{u}}+2 \mathrm{~A}_{2 \mathrm{u}}+4 \mathrm{E}_{\mathrm{u}}$, where $2 \mathrm{~A}_{1 \mathrm{~g}}$ and $5 \mathrm{E}_{\mathrm{g}}$ are Raman activities [19]. The Raman peaks of the curved samples at $369,410,437,565,633$, and $739 \mathrm{~cm}^{-1}$ are characteristic Raman shifts of corundum, consistent with the XRD results. These Raman peaks are related to the vibration of the $\left[\mathrm{AlO}_{6}\right]$ octahedron [20] (Figure 7), of which 410 and $633 \mathrm{~cm}^{-1}$ peaks 
are attributable to $\mathrm{A}_{1 \mathrm{~g}}$, while peaks at $369,437,565$, and $739 \mathrm{~cm}^{-1}$ are attributable to $\mathrm{E}_{\mathrm{g}}$ [20]. The peaks at 369,410 , and $437 \mathrm{~cm}^{-1}$ are caused by the bending vibration of the $\left[\mathrm{AlO}_{6}\right.$ ] group, and those at 565,633 , and $739 \mathrm{~cm}^{-1}$ are caused by the stretching vibration of the $\left[\mathrm{AlO}_{6}\right.$ ] group [21]. There is no diaspore in the XRD test results and in the Raman spectra, which may be related to the different sample states used in the two test methods.

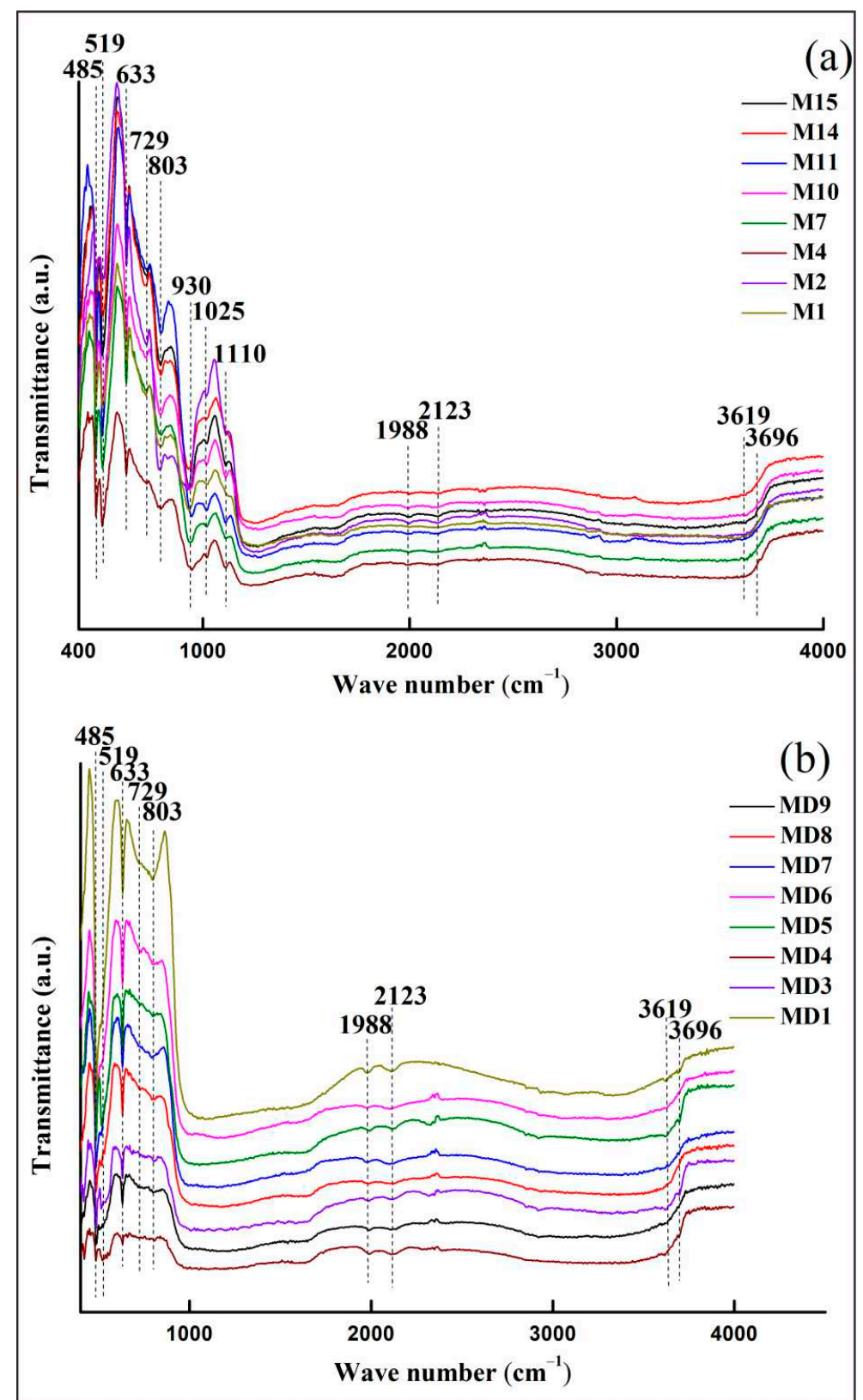

Figure 6. Representative FTIR spectra of sapphire. (a) FTIR spectra of rough samples. (b) FTIR spectra of curved samples. 
Table 3. FTIR peak frequency and attribution of sapphire in this study $\left(\mathrm{cm}^{-1}\right)$.

\begin{tabular}{ccccc}
\hline Sample & Al-O Structure Vibration & Si-O Vibration & -OH Translation & -OH Vibration \\
\hline Sapphire rough sample from Baw-mar mine & $484,517,631,729,800$ & 1025,1110 & 934 & $1986,2120,3619,3680$ \\
Sapphire curved sample from Baw-mar mine & $484,515,632,725,800$ & - & - & $1984,2120,3619,3700$ \\
Thailand [12] & $385,460,600,648,805,1100$ & - & - & $3234,3310,3368$ \\
Shandong [14] & $489,517,633$ & - & - & $3309,3622,3695$ \\
Australia [16] & $436,454,490,519,630$ & - & - & $3186,3233,3310$ \\
\hline
\end{tabular}

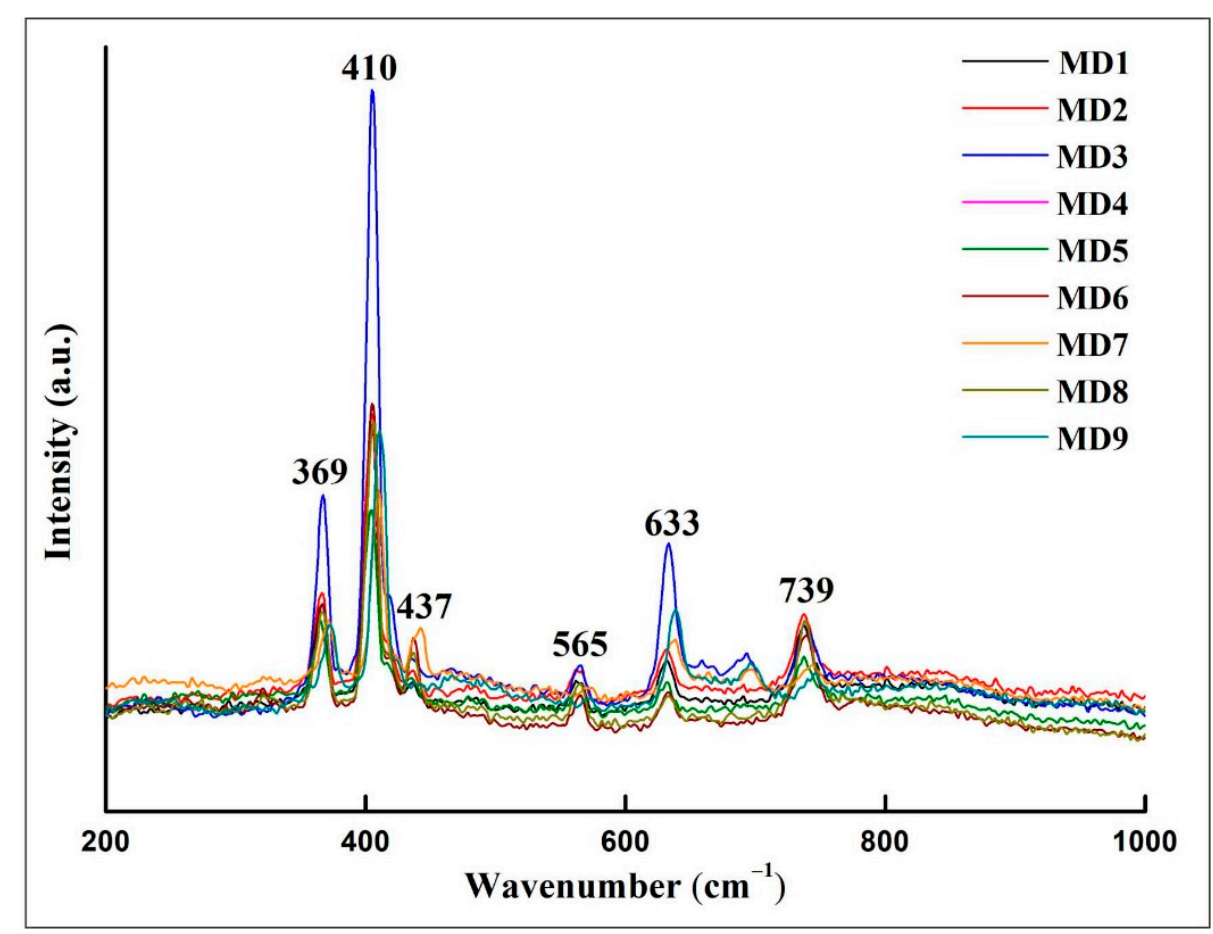

Figure 7. Representative Raman spectra of sapphire.

Compared with the sapphires from Sri Lanka, China, and Australia (Table 4), the Raman shifts of sapphires of different origins are basically consistent, indicating that Raman spectra have a limited effect on sapphire origin traceability and are more suitable for the identification of gem species.

Table 4. Raman peak frequency and attribution of Sapphire. $\left(\mathrm{cm}^{-1}\right)$.

\begin{tabular}{ccccc}
\hline & \multicolumn{2}{c}{ Bending Vibration } & \multicolumn{2}{c}{ Stretching Vibration } \\
\cline { 2 - 5 } [A1O $_{\mathbf{6}}$ ] Group & $\mathbf{A}_{\mathbf{1 g}}$ & $\mathbf{E}_{\mathbf{g}}$ & $\mathbf{A}_{\mathbf{1 g}}$ & $\mathbf{E}_{\mathbf{g}}$ \\
\hline Standard corundum Raman shift & 418 & 378,432 & 645 & 578,751 \\
Sapphire camber sample from Baw-mar mine & 411 & 368,439 & 634 & 565,740 \\
Shandong [15] & 415 & 376,482 & 672 & 574,748 \\
Australia [16] & - & 377,429 & 642 & 750 \\
Sri Lanka [19] & 416 & 379,434 & - & 557,749 \\
\hline
\end{tabular}

\section{Conclusions}

The blue sapphires from Baw-mar mine in Mogok, Myanmar showed distinctly different characteristics from blue sapphires of other origins. The samples contain white clay minerals attached to the surface of their rough stones, which are confirmed to be kaolinite by XRD. They are usually free of solid inclusions. Both XRD and Raman spectroscopy indicate that the matrix's composition is $\mathrm{Al}_{2} \mathrm{O}_{3}$. The content of Fe and $\mathrm{Ti}$ in the XRF test is significantly higher than that of high-quality sapphires. The UV-Vis-NIR spectra are different from those of sapphires of other origins. They contain the characteristic peak 
of $\mathrm{V}^{3+} \mathrm{d}$-d transition. When $\mathrm{Ni}^{2+}$ exists, it will transfer with $\mathrm{Fe}^{3+}$ to aggravate the gray tone of the sapphire. The IR spectra showed three characteristic peaks of kaolinite in the range of $900-1200 \mathrm{~cm}^{-1}$, and confirmed the existence of diaspore. The characteristic peaks in UV-Vis-NIR spectra and IR spectra can be used to identify sapphires in this mine effectively. Based on the microscopic observation, chemical composition, and spectroscopic characteristics, the blue sapphires from Baw-mar mine can be distinguished from sapphires of other origins.

Author Contributions: Conceptualization, S.C. and E.Z.; methodology, S.C.; writing—original draft preparation, S.C., H.T., C.Z., Y.T. and E.Z.; writing-review and editing, S.C. and C.Z.; supervision, E.Z.; funding acquisition, H.T. All authors have read and agreed to the published version of the manuscript.

Funding: This research was supported by the National Natural Science Foundation of China. (Grant No. 51662023).

Data Availability Statement: Not applicable.

Acknowledgments: We are grateful to Editor-in-Chief Helmut Cölfen and Guest Editor Fei Liu for their efficient editorial handling, as well as two anonymous reviewers for their constructive comments and suggestions that greatly improve this manuscript. We appreciate Motai for providing the rough sapphire samples from the Baw-mar mine in Mogok, Myanmar.

Conflicts of Interest: The authors declare that they have no known competing financial interests or personal relationships that could have appeared to influence the work reported in this paper.

\section{References}

1. Zhang, B.L. Systematic Gemology, 2nd ed.; Geological Publishing House: Beijing, China, 2006; pp. 124-125.

2. Palke, A.C.; Wong, J.; Verdel, C.; Ávila, J.N. A common origin for Thai/Cambodian rubies and blue and violet sapphires from Yogo Gulch, Montana, USA? Am. Miner. 2018, 103, 469-479. [CrossRef]

3. Chen, C.Y.; Huang, W.Z.; Shao, T. Study on UV-Visible Spectroscopy of Special Color-changing Sapphire. Spectrosc. Spectr. Anal. 2019, 39, 2470-2473. (In Chinese with English abstract)

4. Harlow, G.E.; Bender, W. A study of ruby (corundum) compositions from the Mogok Belt, Myanmar: Searching for chemical fingerprints. Am. Miner. 2013, 98, 1120-1132. [CrossRef]

5. Palanza, V.; Di Martino, D.; Paleari, A.; Spinolo, G.; Prosperi, L. Micro-Raman spectroscopy applied to the study of inclusions within sapphire. J. Raman Spectrosc. 2008, 39, 1007-1011. [CrossRef]

6. Peucat, J.; Ruffault, P.; Fritsch, E.; Coz, M.B.-L.; Simonet, C.; Lasnier, B. Ga/Mg ratio as a new geochemical tool to differentiate magmatic from metamorphic blue sapphires. Lithos 2007, 98, 261-274. [CrossRef]

7. Kan-Nyunt, H.-P.; Karampelas, S.; Link, K.; Thu, K.; Kiefert, L.; Hardy, P. Blue Sapphires from the Baw Mar Mine in Mogok. Gems Gemol. 2013, 49, 223-232. [CrossRef]

8. Zaw, K.; Sutherland, L.; Yui, T.-F.; Meffre, S.; Thu, K. Vanadium-rich ruby and sapphire within Mogok Gemfield, Myanmar: Implications for gem color and genesis. Miner. Depos. 2014, 50, 25-39. [CrossRef]

9. Soonthorntantikul, W.; Vertriest, W.; Raynaud-Flattot, V.L. An in-Depth Gemological Study of Blue Sapphires from the Baw Mar Mine (Mogok, Myanmar); GIA: Bangkok, Thailand, 2017.

10. Qiu, C.J.; Wang, Y.Q.; Huang, Y.X. Study on color causes and improvement technology of low-quality sapphire in Madagascar. Prog. Laser Optoelectron. 2015, 52, 283-290. (In Chinese with English abstract)

11. Han, X.Z.; Kang, Y.; Feng, X.Q. Research on the color-causing mechanism and color modification of African yellow sapphire. J. Chin. Ceram. Soc. 2019, 47, 990-994. (In Chinese with English abstract)

12. Abduriyim, A. Determination of the origin of blue sapphire using laser ablation inductively coupled plasma mass spectrometry (LA-ICP-MS). J. Gemmol. 2006, 30, 23-36. [CrossRef]

13. Fan, J.L. Research on Color Optimization and Fracture Filling Technology of Ruby and Sapphire. Ph.D. Thesis, East China University of Technology, Beijing, China, 2009; pp. 42-44. (In Chinese with English abstract)

14. Mogmued, J.; Monarumit, N.; Won-In, K.; Satitkune, S. Spectroscopic properties for identifying sapphire samples from Ban Bo Kaew, Phrae Province, Thailand. J. Phys. Conf. Ser. 2017, 901, 12075. [CrossRef]

15. Chen, T.; Yang, M.X. The gemological characteristics and identification of Be diffusion treatment, heat treatment and natural two-color Changle sapphire. Spectrosc. Spectr. Anal. 2012, 32, 651-654. (In Chinese with English abstract)

16. Ding, J.; Li, Z.Y.; Li, S.P. Infrared spectroscopy analysis and discussion of Shandong sapphire. Metrol. Test. Technol. 2011, 38, 54-55. (In Chinese)

17. Xu, Y.F. Study on Gemological Characteristics and Heat Treatment Color Modification Technology of Australian Sapphire. Master Thesis, China University of Geosciences, Wuhan, China, 2019; pp. 24-25. (In Chinese with English abstract) 
18. Ning, P.Y.; Zhang, T.Y.; Ma, H. Infrared spectroscopy-micro confocal laser Raman spectroscopy to study the characteristics of water-containing mineral inclusions in rubies and sapphires. Rock Miner. Test. 2019, 38, 640-648. (In Chinese with English abstract)

19. Giuliani, G.; Dubessy, J.; Banks, D.A.; Lhomme, T.; Ohnenstetter, D. Fluid inclusions in ruby from Asian marble deposits: Genetic implications. Eur. J. Miner. 2015, 27, 393-404. [CrossRef]

20. Zu, E.D.; Sun, Y.D.; Zhang, P.X. Raman spectral analysis of natural and synthetic rubies. Spectrosc. Spectr. Anal. 2010, 30, 2164-2166. (In Chinese with English abstract)

21. Jin, Y.F. Heat treatment of milky sapphire in Sri Lanka. J. Miner. 2015, 35, 550-554. (In Chinese with English abstract) 